\title{
LANDSCAPE PHYTOSOCIOLOGY CONCEPTS AND DEFINITIONS APPLIED TO SERIAL AND CATENAL VEGETATION MAPPING
}

\author{
Frédéric BIORET ${ }^{l}$, Vincent BOULLET ${ }^{l}$, Guillaume CHOISNET ${ }^{1,2}$, Camille ROUX ${ }^{3}$, Gilles THÉBAUD ${ }^{3}$, \\ Christophe PANAÏOTIS ${ }^{4}$, Aurélie CHALUMEAU ${ }^{1}$, Pauline DELBOSC ${ }^{1,4}$, Charlotte DEMARTINI ${ }^{1}$, Christian \\ GAUBERVILLE ${ }^{5}$, Kevin CIANFAGLIONE ${ }^{1}$, Farid BENSETTITI ${ }^{1,6}$, Arnault LALANNE ${ }^{1}$ \\ ${ }^{1}$ Université de Bretagne occidentale, EA 2119 Géoarchitecture, UFR Sciences \& Techniques, 6 avenue Le Gorgeu, \\ F-29200 Brest, France \\ ${ }^{2}$ Conservatoire botanique national du Massif central, le Bourg, F-43280 Chavaniac-Lafayette, France \\ ${ }^{3}$ UNIVEGE, Université Blaise Pascal, 3 Bd Lafayette, F-63000 Clermont-Ferrand France \\ ${ }^{4}$ Conservatoire botanique national de Corse, Office de l'Environnement de la Corse, \\ 14 avenue Jean Nicoli, F-20250 Corte, France \\ ${ }^{5}$ Expert indépendant \\ ${ }^{6}$ UMS 2006 Patrimoine Naturel, Muséum National histoire Naturelle, \\ 36, rue Geoffroy Saint Hilaire, F-75005Paris, France \\ e-mail: frederic.bioret@univ-brest.fr
}

\begin{abstract}
The main concepts and definitions related to dynamic-catenal phytosociology are presented and discussed, in order to share common definitions within the French national program CarHAB dedicated to serial and catenal vegetation typology and mapping. Symphytosociology is based on serial approach and on the vegetation series concept, while Geosymphytosociology is based on catenal approach and on the geoseries concept.
\end{abstract}

Keywords: dynamic-catenal phytosociology, vegetation series, vegetation geoseries

\section{Introduction}

While vegetation can be considered as an indicator of ecological and stational conditions $[6,7]$ it is spatially organized into a pyramidal structure, from the plant individual to the landscape level. This structure corresponds to a stochastic process which gains into complexity [15].

Almost one century after the development of sigmatist phytosociology [4, 13], landscape phytosociology emerged in 1970s and tends to be considered as a new science in the field of geobotany $[31,8,9,10,12,25,26,29]$. Landscape or dynamic-catenal phytosociology aims to integrate dynamic processes within the description of natural and semi-natural vegetations [10].

Two approaches can be distinguished [11]:

- symphytosociology, based on serial approach and on the vegetation series concept, allows to describe the different successional stages, from the pioneer ones to the climacic one, within a homogeneous ecological envelop corresponding to a tessela;

- geosymphytosociology, based on catenal approach and on the geoseries concept, considers the different vegetation series organized along ecological gradients and that can be gathered within a homogeneous geomorphological envelop corresponding to a catena.

The review of the concepts, evolution and actual trends of landscape phytosociology were presented in a historical and synthetic article [12]. 
Vegetation mapping applications based on both symphytosociological and geosymphytosociological approaches are developped by several authors [19, 27, 3, 2]; vegetation mapping methodologies based on serial and catenal approach in Europe are presented and analysed in a recent bibliographical synthesis [5].

Several applications of landscape phytosociology to land management and nature conservation have been proposed [1, 11, 22, 23, 24].

The main purpose of this paper is to clarify the classical definitions related to landscape phytosociology and propose pragmatic definitions, while new definitions dealing either with symphytosociology or geosymphytosociology are proposed in order to characterise more precisely the different ecological situations. These synthetic definitions could be used by field operators in charge of description of vegetation series and geoseries typologies and mapping, especially within the French national programme of cartography of habitats and vegetations (CarHAB), launched in 2011 by the French Ministry of Ecology. The aim of this programme is to realize vegetation mapping of the whole metropolitan national territory at the scale of $1: 25$ 000, and be ended up to 2025. A working group focused on the dynamic-catenal approach of vegetations and its mapping applications, worked on the landcape phytosociology concepts and definitions that will be shared by the phytosociologist community working for the CarHAB programme.

\section{Definitions}

A first set of definitions concerns symphytosociology, while a second set deals with geosymphytosociology. Phytosociological and symphytosociological considerations only concerns tracheophytic syntaxa. Each definition can be completed by some comments.

\section{SYMPHYTOSOCIOLOGY}

Vegetation series: conceptual dynamic unit gathering plant communities likely to be present within similar tessellas and presenting the same potentiality of vegetation which final stage corresponds to the series head.

Vegetation series is synonym of synassociation or sigmetum and constitutes the elementar unit of symphytosociology.

The series includes primary communities as well as substitution ones.

The potentiality is evaluated along a short temporal scale: the series head corresponds to the natural potential vegetation $[30,21,20]$.

The series head is characterized by an elementary syntaxon nomenclaturly validated: association or subassociation.

Tessella (French: tesselle, Spanish: tesela, Italian: tessela, tessella): spatial unit of variable superficial, ecologically homogeneous, presenting a unique vegetation potentiality.

A tessella corresponds to an ecological compartment.

Individual of series: concrete element gathering one or several plant communities of one vegetation series, present within a tessella.

Climatophilous series: vegetation series linked to the mesoclimate (or topoclimate in some cases) and developping in medium pedological conditions (mesophilous).

Within the same mesoclimat, different climatophilous series can occur (ex.: presence of 
an acidiphilous Fagus forest, an acidiclinous Fagus forest and a neutrophilous Fagus forest along a toposequence).

Topoaerophilous series: vegetation series linked to particular atmospheric conditions, in slope situation and confinement.

Edaphophilous series: vegetation series strongly influenced by edaphical constraints.

Edaphoxerophilous series: vegetation series, generally azonal, developed on xeric superficial soils (lithosols, arenosols).

Temporhygrophilous (or temporihygrophilous) series: vegetation series, generally azonal, influenced by temporary engorged soils: inundated soils or wet soils during a significant part of the year (alternative engorged soils).

Edaphohygrophilous series: vegetation series, generally azonal, linked to hydromorphic environments: lakes, rivers, marshes, salt marshes, peatbogs.

Vegetation series variant: subdivision of the series associated to internal variability of tessellas, which determinism can be abiotic: ionic, trophic, hydric, biotic...: agricultural and forest practises, fire... or geographic. It takes place within the same serial potentiality (unique series head).

The terms of subseries and fasciation have been proposed [27] but their interpretation can be very variable. The proposal of variant doesn't finally fix the concept.

Sigmafacies (series facies): repetitive physiognomic expression of the series characterised by a particular combination of syntaxa.

Holoseries: complete series, characterised by at least two perennial dynamic stages, which mature one is forest.

Permaseries: series with only one perennial permanent stage within a tessella characterized by strong ecological constraints.

The syntaxon regeneration can include a pioneer therophytic stage.

Curtaseries: truncated series, caracterised by at least two dynamical perennial stages, which mature stage, due to ecological constraints, is a non-forest one.

In 2003, Lazare and Lanniel define a new concept, the mesoserie, replaced by the term of curtaserie or truncated serie [15], as synonym of minoriseries [27]. It concerns intermediary cases between permaseries and series, where the vegetations are submitted to less extreme ecological constraints than permaseries, allowing the appearance of the first steps of succession, but strong enough to prevent the natural potential vegetation to reach the forest stage. For grammatical reasons, Rivas-Martínez (2011) proposes to name this concept "minoriserie" instead of "curtaserie". For this author, these terms are synonymous.

Recently, Lazare proposed to distinguish curtaseries, which dynamic is regularly submitted to major perturbations such as avalanches and river flooding, and minoriseries for vegetations which dynamic is blocked due to permanent ecological constraints (essentially edaphic and climatic constraints) [17].

Theroseries: one stage vegetation series corresponding to a seasonal annual community, low stratified, within an instable tessela, characterized by strong ecological constraints. 
50 F. BIORET, V. BOULLET, G. CHOISNET, C. ROUX, G. THÉBAUD, C. PANAÏOTIS, A. CHALUMEAU, P. DELBOSC, C. DEMARTINI, C. GAUBERVILLE, K. CIANFAGLIONE, F. BENSETTITI, A. LALANNE

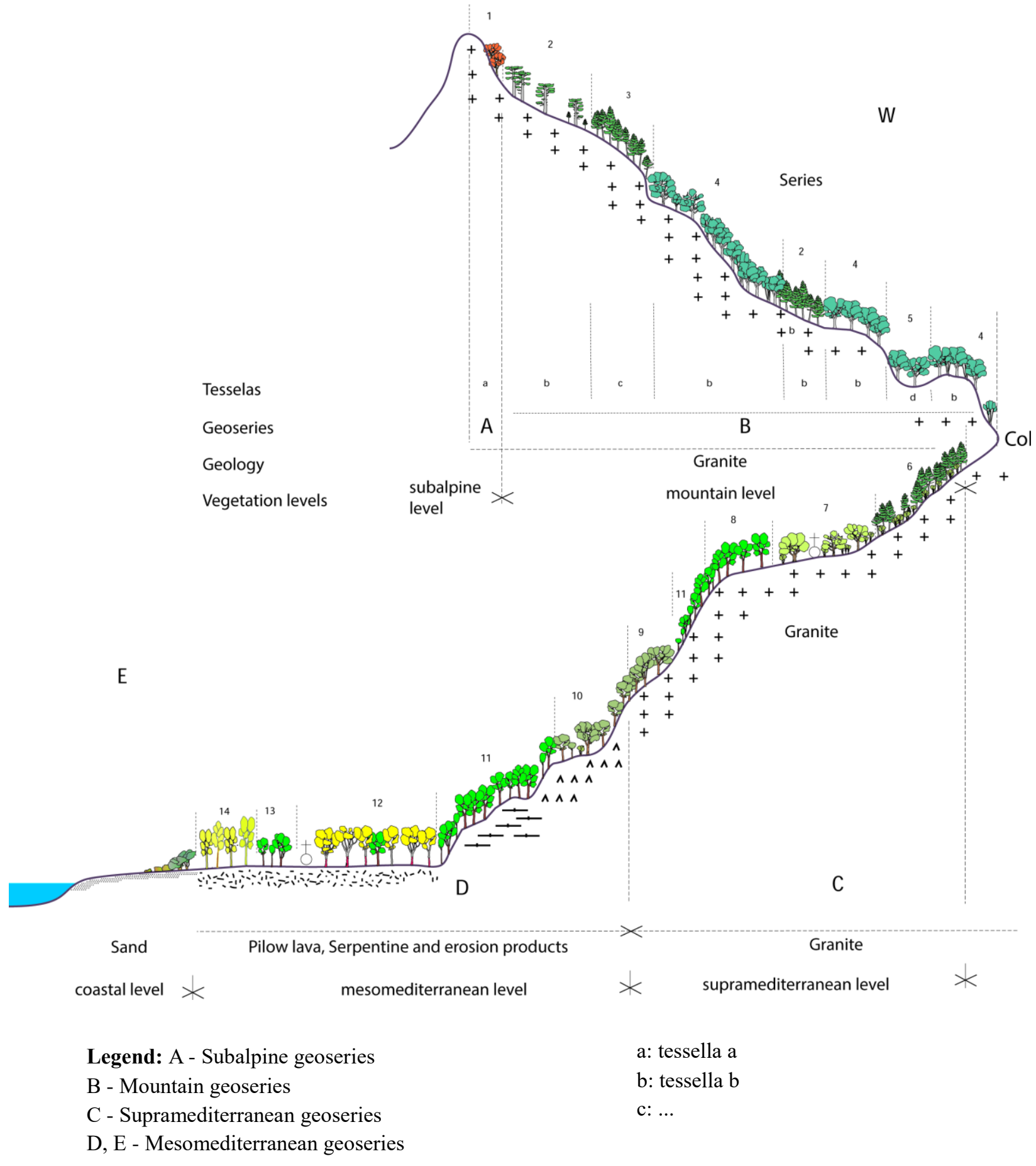

1 Climatophilous subalpine series of Sorbo aucupariae-Acero pseudoplatani sigmetum

(Subalpine Maple forest with Mountain Ash)

2 Mountain climatophilous series of Galio rotundifolii-Pino laricii subass. luzuletosum pedemontanae sigmetum

(Mesophilous mountain Corsican Pine forest with Luzula pedemontana)

3 Mountain edaphoxerophilous series of Galio rotundifolii-Pino laricii subass. antyllidetosum hermanniae sigmetum

(Xerophilous mountain Corsican Pine forest with Anthyllis hermanniae)

4 Mountain climatophilous series of Poo balbisii-Fago sylvaticae sigmetum 
(Mountain mesophilous Beech forest with Poa balbisii)

5 Mountain climatophilous series of Pyrolo minoris-Fago sylvaticae sigmetum

(Mountain cold Beech forest with Common wintergreen)

6 Supramediterranean climatophilous series of Galio rotundifolii-Pino laricii subass. ericetosum arboreae sigmetum

(Supramediterranean Corsican Pine forest with Tree-heath)

7 Supramediterranean edaphophilous series of Digitalo luteae-Castano sativae sigmetum

(Supraméditerranean edaphophilous Chestut Tree forest with Yellow Foxglove)

8 Supraméditerranean edaphoxerophilous series of Ilici sempervirentis-Querco ilicis sigmetum

(Supraméditerranean édaphoxerophilous Evergreen Oak forest with Holly)

9 Supraméditerranean climatophilous series of Oenanthe pimpineloidis-Querco pubescentis sigmetum

(Supraméditerranéenne climatophilous Downy Oak forest with Corky-fruited Water-dropwort)

10 Mesomediterranean climatophilous series of Galio scabri-Querco ilicis subass. quercetosum pubescentis sigmetum

(Mesoméditerranean climatophilous Downy Oak forest with Galium scabrum)

11 Mesomediterranean climatophilous series of Galio scabri-Querco ilicis sigmetum

(Mesomediterranean Evergreen Oak forest with Galium scabrum)

12 Mesomediterranean climatophilous series of Galio scabri-Querco suberis sigmetum

(Mesomediterranean Cork Oak forest with Galium scabrum)

13 Mesomediterranean (lower horizon) climatophilous series of Galio scabri-Querco ilicis subass. fraxinetosum sigmetum

(Coastal thermophilous Evergreen Oak forest with Flowering Ash)

14 Mesohygrophilous alluvial series of Carici remotae-Fraxino angustifoliae sigmetum

(Alluvial narrow-leaved ash forest with Carex remota)

\section{GEOSYMPHYTOSOCIOLOGY}

Vegetation geoseries: conceptual catenal unit gathering different sigmataxa which tesselas constitute a geomorphological and bioclimatic homogeneous unit.

Geoseries is synonymous of geosynassociation or geosigmetum and constitutes the elemental unit of geosymphytosociology.

Catena: geomorphological and bioclimatic of variable size, gathering one or several vegetation series.

Geoseries individual: concrete element gathering one or several individuals of vegetation series inside one catena.

Geosigmafacies (geoseries facies): repetitive physiognomic expression of the geoseries characterized by a particular combination of syntaxa.

Geopermaseries: conceptual catenal unit gathering several permaseries within a geomorphologic and bioclimatic entity.

Geopermaseries is synonym to geopermasigmetum.

Geocurtaseries: conceptual catenal unit gathering several curtaseries within a geomorphologic and bioclimatic entity.

Geocurtaseries is synonym to geocurtosigmetum.

\section{Symphytosociological and geosymphytosociological Nomenclature}

Nomenclature of series and geoseries should necessary be completed by a diagnose and the citation of the syntaxon name which is the series head. We don't follow the recent proposals of Izco (2014) for the nomenclature of series and geoseries.

Vegetation series: name of the association series head $+(-0)$ sigmetum. 


\section{F. BIORET, V. BOULLET, G. CHOISNET, C. ROUX, G. THÉBAUD, C. PANAÏOTIS, A. CHALUMEAU, P. DELBOSC, C. DEMARTINI, C. GAUBERVILLE, K. CIANFAGLIONE, F. BENSETTITI, A. LALANNE}

Example of series which head is an association: Scutellario columnae-Ostryo carpinifoliae sigmetum Biondi 2002.

Vegetation geoseries: name of the association of the head of the dominant series $+(-0)$ geosigmetum.

Example: Hyperico androsaemi-Alno glutinosae geosigmetum Loidi, Biurrun, Campos, García-Mijangos \& Herrera 2010.

\section{REFERENCES}

1. Biondi, E., 1994, The Phytosociological approach to landscape study, Annali di Botanica (Roma), 52: 135141.

2. Biondi, E., Casavecchia, S., Pesaresi, S., 2011, Phytosociological synrelevés and plant landscape mapping: From theory to practice, Plant Biosystems, 145 (2): 261-273.

3. Blasi, C., 2010, La vegetazione d'Italia, con carta delle series di vegetazione in scale 1: 500.000" . [Vegetation of Italia, with vegetation series mapping at 1: 500.000 scale].

4. Braun-Blanquet, J., 1951, Pflanzensoziologie. Grundüge der vegetationskunde [Plant Sociology. Basic principles for vegetation Science], Wien, Springer.

5. Chalumeau, A., Bioret, F., 2013, Méthodologie de cartographie phytosociologique en Europe: approches symphytosociologique et géosymphytosociologique. Synthèse bibliographique [Methodology of phytosociological mapping in Europe, Symphytosociological and geosymphytosociological approaches. Bibliographical review] Rapport Institut de Géoarchitecture - Université de Bretagne Occidentale, Ministère de l'Écologie, du Développement Durable et de l'Énergie.

6. Clements, F.E., 1920, Plant Indicators, Washington DC, Carnegi Institute.

7. Dale, V.H., Beyeler, S.C., 2001, Challenges in the development and use of ecological indicators, Ecological Indicators, 1: 3-10.

8. Géhu, J-M., 1977, Le concept de sigmassociation et son application à l'étude du paysage végétal des falaises Atlantiques Françaises [The concept of sigmassociation and its appplication to the study of French Atlantic cliffs], Vegetatio, 34 (2): 117-125.

9. Géhu, J.-M., 1979, Pour une approche nouvelle des paysages végétaux: la symphytosociologie, [Symphytosociology as a new approach of vegetal landscapes], Bulletin de la Société Botanique de France, Lettres Botaniques, 126 (2): 213-223.

10. Géhu, J.-M., 1991, L'analyse symphytosociologique et géosymphytosociologique de l'espace. Théorie et méthodologie [Symphytosociological and geosymphytosociological space analysis. Theory and methodology], Colloques phytosociologiques, XVII, Phytosociologie et paysage: 11-46.

11. Géhu, J.-M, 2004, La symphytosociologie trente ans plus tard (1973-2003). Concepts, systématisation, applications [Symphytosociology three decades later (1973-2003). Concepts, systematisation, applications], Bulletin de la Société Botanique du Centre-Ouest, NS, 35: 63-80.

12. Géhu, J.-M., 2006, Dictionnaire de sociologie et synécologie végétales, [Dictionary of plant sociology and synecology], Stuttgart, Cramer.

13. Géhu, J.M., Rivas-Martinez, S., 1981, Notions fondamentales de phytosociologie [Fundamental notions of phytosociologiy]. In: Syntaxonomie, Dierschke, H., (ed.), Ber Intern Symposium IV-V: 5 - 53, Vaduz, Cramer.

14. Izco, J., 2014, Symphytosociological nomenclature: new proposals, Lazaroa, 35:191-194.

15. Lazare, J.-J., 2009, Phytosociologie dynamico-caténale et gestion de la biodiversité, [Dynamic-catenal Phytosociology and biodiversity management], Acta Botanica Gallica, 156 (1): 46-61.

16. Lazare, J.-J., 2013, La série édaphoxérophile montagnarde béarnaise héliophile du chêne sessiliflore [Quercus petraea (Mattuschka) Liebl.]: Erico vagantis-Querco petraeae sigmetum nov." [Heliophilous mountain Béarn sessiliflore oak [Quercus petraea (Mattuschka) Liebl.] edaphoxerophilous series: Erico vagantis-Querco petraeae sigmetum nov.], Le Journal de Botanique de la Société Botanique de France, 63: $55-62$. 
17. Lazare, J.-J., 2018, La phytosociologie paysagère : vers une gestion intégrée de la biodiversité [Landscape Phytosociology: towards a biodiversity integrated management], Documents Phytosociologiques Série 3, vol. 9 , in press.

18. Lazare, J.-J., Lanniel, K., 2003, Une sous-association nouvelle de fourrés du Rubo ulmifolii-Tametum communis du littoral basque [A new bush subassociation of the Rubo ulmifolii-Tametum communis in Basque country coastal zone], Journal de Botanique de la Société Botanique de France, 21: 33-35.

19. Loidi, J., 1991, Vegetation series: its use for small scale geobotanical mapping, Phytocoenosis, Cartographiae Geobotanicae, 2 (suppl. 3): 119-122.

20. Loidi, J., Fernandez-Gonzalez, F., 2012, Potential natural vegetation: reburying or reboring?, Journal of Vegetation Science, 23: 596-604.

21. Mucina, L., 2010, Floristic-phytosociological approach, potential natural vegetation, and survival of prejudice, Lazaroa, 31: 173-182.

22. Pedrotti, F., 2004, Cartografia geobotanica, Bologna: Pitagora E.

23. Pedrotti, F., 2013, Plant and Vegetation Mapping, Berlin, Springer.

24. Penas, A., del Río, S., L. Herrero, L., 2005, A new methodology for the quantitative evaluation of the conservation status of vegetation: the potentiality distance index (PDI), Fitosociologia, 42 (2): 23-31.

25. Rivas-Martínez, S., 1982, Étages bioclimatiques, secteurs chorologiques et séries de végétation de l'Espagne méditerranéenne [Bioclimatic floors, chorologic sectors and vegetation series of the Mediterranean Spain], Ecologia Mediterranea, VIII (1-2): 275-288.

26. Rivas-Martínez, S., 2005, Notions on dynamic-catenal phytososiology as a basis of landscape science, Plant Biosystems, 139 (2): 135-144.

27. Rivas-Martínez, S., 2007, Mapa de series, geoseries y geopermaseries de vegetación de España [Series, Geoseries and Geopermaseries vegetation mapping in Spain], Itinera Geobotanica NS 17.

28. Rivas-Martínez, S., 2011, Mapa de series, geoseries y geopermaseries de vegetación de España (Mémoria del mapa de vegetacion potential de España) parte II [Series, Geoseries and Geopermaseries vegetation mapping in Spain (Memory of the map of the potential vegetation of Spain) part II], Itinera Geobotanica, 18 (2): 425800 .

29. Theurillat, J.-P., 1992, L'analyse du paysage végétal en symphytoceonologie: ses niveaux et leurs domaines spatiaux [Vegetal landscape analysis in Symphytocoenology: its levels and spatial domains], Bulletin d'Écologie, 23 (1): 83-92.

30. Tüxen, R., 1956, Die heutige potentielle natürliche Vegetation als Gegenstand der Vegetationskartierung." [The actual natural potential vegetation as object of the vegetation mapping], Angewandte Pflanzensoziologie, 13: 5-55.

31. Tüxen, R., 1979, Sigmeten und Geosigmeten, ihre Ordung und ihre Bedeutung für Wissenschaft, Naturschutz und Planung [Sigmeta anf Geosigmeta, their place and signification for Science, Nature protection and Management], Biogeographica, 16: 79-92.

\section{CONCEPTE ȘI DEFINIT⿱II ALE FITOSOCIOLOGIEI PEISAGERE APLICATE ÎN CARTOGRAFIEREA SERIILOR ȘI CATENELOR DE VEGETAŢIE}

\section{(Rezumat)}

Sunt prezentate şi discutate principalele concepte și definiții legate de fitosociologia dinamic-catenală din cadrul programului naţional francez $\mathrm{CarHAB}$ dedicat tipologiei și cartografierii vegetației seriale și catenale. Simfitosociologia se bazează pe abordarea serială şi pe conceptul de serii de vegetație, în timp ce Geosimfitosociologia se bazează pe abordarea catenală și pe conceptul de geoserii. 